Article

\title{
Antiparasitic Action of Lactobacillus casei ATCC 393 and Lactobacillus paracasei CNCM Strains in CD-1 Mice Experimentally Infected with Trichinella britovi
}

\author{
Zsolt Boros ${ }^{1,+}$, Mihai Horia Băieș ${ }^{1,+}$, Dan Cristian Vodnar ${ }^{2,3}$ (D) Călin Mircea Gherman ${ }^{1}$ (D), Silvia-Diana Borșan ${ }^{1}$, \\ Anamaria Cozma-Petrut ${ }^{4, *(\mathbb{D})}$, Menelaos Lefkaditis ${ }^{5}$, Adriana Györke ${ }^{1}$ (D) and Vasile Cozma ${ }^{1,6}$ (D)
}

Citation: Boros, Z.; Băieș, M.H.; Vodnar, D.C.; Gherman, C.M.; Borșan, S.-D.; Cozma-Petruț, A.; Lefkaditis, M.; Györke, A.; Cozma, V. Antiparasitic Action of Lactobacillus casei ATCC 393 and Lactobacillus paracasei CNCM Strains in CD-1 Mice Experimentally Infected with Trichinella britovi. Pathogens 2022, 11, 296. https://doi.org/10.3390/ pathogens11030296

Academic Editor: Junhua Wang

Received: 22 January 2022

Accepted: 23 February 2022

Published: 25 February 2022

Publisher's Note: MDPI stays neutral with regard to jurisdictional claims in published maps and institutional affiliations.

Copyright: (C) 2022 by the authors. Licensee MDPI, Basel, Switzerland. This article is an open access article distributed under the terms and conditions of the Creative Commons Attribution (CC BY) license (https:// creativecommons.org/licenses/by/ $4.0 /)$.
1 Department of Parasitology and Parasitic Diseases, Faculty of Veterinary Medicine, University of Agricultural Sciences and Veterinary Medicine, 400372 Cluj-Napoca, Romania; zsolt.boros@usamvcluj.ro (Z.B.); mihai-horia.baies@usamvcluj.ro (M.H.B.); calin.gherman@usamvcluj.ro (C.M.G.); silvia.borsan@usamvcluj.ro (S.-D.B.); adriana.gyorke@usamvcluj.ro (A.G.); vasile.cozma@usamvcluj.ro (V.C.)

2 Department of Food Science, Faculty of Food Science and Technology, University of Agricultural Sciences and Veterinary Medicine, 400372 Cluj-Napoca, Romania; dan.vodnar@usamvcluj.ro

3 Institute of Life Sciences, University of Agricultural Sciences and Veterinary Medicine, 400372 Cluj-Napoca, Romania

4 Department of Bromatology, Hygiene, Nutrition, Faculty of Pharmacy, "Iuliu Haţieganu" University of Medicine and Pharmacy, 400349 Cluj-Napoca, Romania

5 Laboratory of Microbiology and Parasitology, Department of Veterinary Medicine, School of Health Sciences, University of Thessaly, 43100 Karditsa, Greece; mLefkaditis@vet.uth.gr

6 Academy of Agricultural and Forestry Sciences Gheorghe Ionescu-Siseşti (A.S.A.S.), 011464 Bucharest, Romania

* Correspondence: anamaria.cozma@umfcluj.ro; Tel.: +40-745-693-208

$\dagger$ These authors contributed equally to this work.

\begin{abstract}
Nematodes of the genus Trichinella are among the most widespread parasites of domestic and wild omnivores and predatory animals. The present study aimed to evaluate the antiparasitic effect of Lactobacillus casei ATCC 393 (original) and L. paracasei CNCM in CD-1 mice experimentally infected with Trichinella britovi. Four groups of 20 mice (10 females and 10 males/group) were used, with two control (C) groups and two experimental (E) groups, in which each animal received a daily oral dose of $100 \mu \mathrm{L}$ of $10^{5} \mathrm{CFU} / \mathrm{mL}$ probiotics in Ringer's solution. On day 7 , all mice (except the negative control group) were infected orally with Trichinella (100 larvae/animal) as well as the two probiotics. On day 9 post-infection (p.i.), 10 mice/group were euthanized, and the presence of adult parasites in the intestinal content and wall was tested. On day 32 p.i., 10 mice/group were euthanized, then trichinoscopy and artificial digestion were performed to assess the muscle infection with $T$. britovi. On day 9 p.i., the experimental group pretreated with L. casei ATCC $393(6.3 \pm 3.03)$ showed a significantly lower number of adult parasites in the intestinal wall compared with the positive control group (24.6 \pm 4.78$)$. Additionally, a significantly lower adult parasite count in the intestinal wall was registered in female mice pretreated with $L$. paracasei CNCM $(7.4 \pm 4.71)$ compared to female mice from the positive control $(29.0 \pm 5.17)$. No statistically relevant results were obtained concerning the male mice or the data obtained at 32 days p.i., irrespective of mice gender.
\end{abstract}

Keywords: mice; probiotics; Trichinella britovi

\section{Introduction}

Trichinellosis is a zoonotic disease caused by nematodes of the genus Trichinella, which are among the most widespread parasites of domestic and wild omnivores and predatory animals [1]. Hosts can acquire infection by the consumption of raw or undercooked infected meat. The adults and larvae of Trichinella spp. reside in the same host, causing various 
adverse effects [2]. To date, two species of Trichinella have been reported in Romanianamely, T. spiralis (in domestic mammals) and T. britovi (in wild animals), but co-infections can also occur [3]. Trichinellosis is still present in Romania due to the local traditions and culinary customs that favor the transmission to humans. Humans can become infected through the consumption of untested raw meat, especially pork and wild boar [4,5], which has led to multiple outbreaks over the years [6,7]. The treatment of trichinellosis includes the use of benzimidazole derivates, such as albendazole or mebendazole [8,9]. Recently, the interest in developing different anthelmintic treatments that are both efficacious and safe has been increasing. Particular attention has been given to the potential anti-parasitic effect of probiotics [10].

Probiotics are live microorganisms that can provide a health benefit to the host when administered in adequate amounts [11]. Among them, lactobacilli are the most commonly used probiotics [12]. The Lactobacillus genus contains over $180 \mathrm{Gram}$-positive, anaerobic or microaerophilic, rod-shaped, non-spore-forming bacteria species [13].

Several studies suggest that probiotics can decrease the pathogenicity of parasites and, consequently, influence the course of parasitic infections [14]. In this regard, probiotics main mechanisms of action are related to their ability to compete with pathogens for adhesion sites, enhance intestinal mucosal barrier activity, produce antimicrobial agents, and regulate the host's immune responses [15,16]. A good example, in this case, is an in vivo study conducted on gerbils (Meriones unguiculatus) that were experimentally infected with Gardia lamblia trophozoites and treated with $10^{8} \mathrm{CFU}$ of Lactobacillus johnsonii La1 for seven days prior to parasite inoculation. During the study, no morphological damage to the intestinal epithelium was observed, but a reduction in active trophozoites and infection length was noticed [17]. Regarding nematodes, oral supplementation with Lactobacillus rhamnosus (JB-1) at a dose of $1 \times 10^{9} \mathrm{CFU} /$ day significantly accelerated Trichuris muris larvae removal in mice. This was accompanied by the upregulation of anti-inflammatory cytokine IL-10 levels and mucus-secreting epithelial cell numbers [18]. The positive effects of probiotic bacteria, such as reducing the parasite burden and pathological changes in experimental trichinellosis, have been previously described in several studies [19-23].

The most efficient manner of keeping the human population safe against trichinellosis is to eliminate the positive animals from human consumption. The use of probiotics in this parasitic infection is still in its infancy and they can only be used in experimental models. However, little is known concerning the effect of probiotics on species of Trichinella other than T. spiralis. Therefore, the present study aimed to evaluate the antiparasitic effect of two different probiotic strains of lactobacilli, Lactobacillus casei ATCC 393 (original) and L. paracasei CNCM (commercial product), in CD-1 mice experimentally infected with T. britovi.

\section{Results}

The mean number of adults ( 9 days p.i.) and larvae (32 days p.i.) of T. britovi in the experimental groups can be seen in Table 1 (for all mice), Table 2 (for female mice), and Table 3 (for male mice). On the 9th and 32nd days after T. britovi infection (p.i.), the number of adult parasites and larvae found in the intestines (content and walls) and muscle (by trichinoscopy and artificial digestion) of CD-1 mice was higher in the positive control group than in the experimental groups that were pretreated with one of the two probiotic strains (Table 1, Table 2, Table 3). However, significant differences were registered for the number of adult parasites in the intestinal wall only in mice pretreated with L. casei (per total, and in female mice) and in female mice pretreated with L. paracasei (Table 1, Table 2). 
Table 1. The mean number ( \pm SEM) of adults (9 days p.i.) and larvae (32 days p.i.) of T. britovi in the experimental groups.

\begin{tabular}{|c|c|c|c|c|c|c|c|}
\hline & & NC & PC & L. casei & L. paracasei & $F_{(2,29)}$ & $p$ \\
\hline \multirow{2}{*}{$\begin{array}{l}\text { Day } 9 \text { p.i. } \\
\text { Adults }\end{array}$} & Intestinal content & 0 & $41.3 \pm 6.24^{\mathrm{a}}$ & $15.3 \pm 6.84^{\mathrm{a}}$ & $40.4 \pm 9.76^{\mathrm{a}}$ & 3.61 & 0.0408 \\
\hline & $\begin{array}{c}\text { Intestinal wall } \\
\text { (artificial digestion) }\end{array}$ & 0 & $24.6 \pm 4.78^{a}$ & $6.3 \pm 3.03^{b}$ & $11.7 \pm 4.29 \mathrm{ab}$ & 5.259 & 0.0118 \\
\hline Day 32 p.i. & Trichinoscopy & 0 & $200.1 \pm 26.98^{a}$ & $186.6 \pm 25.76^{a}$ & $238.4 \pm 10.32^{a}$ & 1.446 & 0.2532 \\
\hline Larvae & Artificial digestion & 0 & $2967.6 \pm 134.08$ & $2452.7 \pm 138.72$ & $2895.0 \pm 249.05$ & 2.348 & 0.1148 \\
\hline
\end{tabular}

SEM-standard error of mean; p.i. —-post-infection; NC—negative control group, uninfected and untreated PC - positive control group, infected with 100 larvae/animal of T. britovi and untreated; L. casei-experimental group L. casei ATC 393, infected with 100 larvae/animal of T. britovi and treated with L. casei $10^{5} \mathrm{CFU} / \mathrm{mL}$ in $100 \mu \mathrm{L}$; L. paracasei - experimental group L. paracasei CNCM, infected with 100 larvae/animal of T. britovi and treated with $L$. paracasei $10^{5} \mathrm{CFU} / \mathrm{mL}$ in $100 \mu \mathrm{L} ; F$-statistical value (degree of freedom); $p$-value $<0.05$ was considered significant. Values with no common superscript in a column within an experiment were significantly different $(p<0.05){ }^{\text {a }}$-these values are not statistically significant. ${ }^{\mathrm{b}}$-These values are significantly different $(p$ $<0.05)$ from those with superscript ${ }^{a}$. ${ }^{a}$ - these values are not significantly different from those with superscript ${ }^{a b}$.

Table 2. The mean number ( \pm SEM) of adults (9 days p.i.) and larvae (32 days p.i.) of T. britovi in female mice from the experimental groups.

\begin{tabular}{|c|c|c|c|c|c|c|c|}
\hline & & NC & PC & L. casei & L. paracasei & $F_{(2,14)}$ & $p$ \\
\hline \multirow{2}{*}{$\begin{array}{l}\text { Day } 9 \text { p.i. } \\
\text { Adults }\end{array}$} & Intestinal content & 0 & $42.6 \pm 4.37^{\mathrm{a}}$ & $7.4 \pm 6.41^{a}$ & $41.6 \pm 16.95^{a}$ & 3.467 & 0.0648 \\
\hline & $\begin{array}{c}\text { Intestinal wall } \\
\text { (artificial digestion) }\end{array}$ & 0 & $29.0 \pm 5.17^{a}$ & $4.8 \pm 1.53^{b}$ & $7.4 \pm 4.71^{b}$ & 10.331 & 0.0025 \\
\hline Day 32 p.i. & Trichinoscopy & 0 & $223.8 \pm 40.15^{\mathrm{a}}$ & $212.2 \pm 33.91^{\mathrm{a}}$ & $221.8 \pm 8.02^{\mathrm{a}}$ & 0.041 & 0.9601 \\
\hline Larvae & Artificial digestion & 0 & $2751.0 \pm 203.76^{a}$ & $2447.4 \pm 235.29^{a}$ & $2650.0 \pm 263.63^{a}$ & 0.431 & 0.6595 \\
\hline
\end{tabular}

SEM-standard error of mean; p.i. —post-infection; NC-negative control group, uninfected and untreated, PC - positive control group, infected with 100 larvae/animal of T. britovi and untreated; L. casei-experimental group L. casei ATC 393, infected with 100 larvae/animal of T. britovi and treated with L. casei $10^{5} \mathrm{CFU} / \mathrm{mL}$ in $100 \mu \mathrm{L} ;$ L. paracasei - experimental group L. paracasei CNCM, infected with 100 larvae/animal of T. britovi and treated with $L$. paracasei $10^{5} \mathrm{CFU} / \mathrm{mL}$ in $100 \mu \mathrm{L} ; F$-statistical value (degree of freedom); $p$-value $<0.05$ was considered significant. Values with no common superscript in a column within an experiment were significantly different $(p<0.05){ }^{a}$-these values are not statistically significant. ${ }^{b}$-These values are significantly different $(p$ $<0.05)$ from those with superscript ${ }^{\text {a }}$.

Table 3. The mean number ( \pm SEM) of adults ( 9 days p.i.) and larvae (32 days p.i.) of T. britovi in male mice from the experimental groups.

\begin{tabular}{|c|c|c|c|c|c|c|c|}
\hline & & NC & PC & L. casei & L. paracasei & $F_{(2,14)}$ & $p$ \\
\hline \multirow{2}{*}{$\begin{array}{l}\text { Day } 9 \text { p.i. } \\
\text { Adults }\end{array}$} & Intestinal content & 0 & $40.0 \pm 12.45^{\mathrm{a}}$ & $23.2 \pm 11.77^{\mathrm{a}}$ & $39.2 \pm 11.84^{\mathrm{a}}$ & 0.621 & 0.5537 \\
\hline & $\begin{array}{c}\text { Intestinal wall } \\
\text { (artificial digestion) }\end{array}$ & 0 & $20.2 \pm 8.14^{\mathrm{a}}$ & $7.8 \pm 6.15^{\mathrm{a}}$ & $16.0 \pm 7.16^{a}$ & 0.768 & 0.4854 \\
\hline Day & Trichinoscopy & 0 & $176.4 \pm 37.19^{a}$ & $161.0 \pm 38.82^{\mathrm{a}}$ & $255.0 \pm 16.65^{a}$ & 2.408 & 0.1321 \\
\hline Larvae & Artificial digestion & 0 & $3184.2 \pm 126.20^{\mathrm{a}}$ & $2458.0 \pm 176.67^{a}$ & $3140.0 \pm 423.79^{a}$ & 2.193 & 0.1543 \\
\hline
\end{tabular}

SEM-standard error of mean; p.i.-postinfection; NC—negative control group, uninfected and untreated; PC positive control group, infected with 100 larvae/100 animal of T. britovi and untreated; L. casei-experimental group L. casei ATC 393, infected with 100 larvae/animal of T. britovi and treated with L. casei $10^{5} \mathrm{CFU} / \mathrm{mL}$ in $100 \mu \mathrm{L}$; L. paracasei-experimental group L. paracasei CNCM, infected with 100 larvae/animal of T. britovi and treated with $L$. paracasei $10^{5} \mathrm{CFU} / \mathrm{mL}$ in $100 \mu \mathrm{L} ; F$-statistical value (degree of freedom); $p$-value $<0.05$ was considered significant. Values with no common superscript in a column within an experiment were significantly different $(p<0.05) .{ }^{\mathrm{a}}$-these values are not statistically significant.

\section{Discussion}

Experimental studies regarding the use of probiotics against helminthic infections are scarce [24]. To the best of our knowledge, this is the first study that aimed to evaluate the antiparasitic effect of Lactobacillus strains against $T$. britovi in a murine experimental model. The current study emphasizes the antiparasitic effect of $L$. casei and L. paracasei against $T$. britovi (adults) infection in mice. The mice treated with these two probiotic strains showcased an overall lower parasite count (both adults and larvae) but with statistically 
significant results found only in the case of adult parasites compared to the control groups. The observed differences in adult worm count could be linked to the effect of the used probiotics on the development of the larvae to the adult stage, yet not affecting the reproductive capability of the adult worms. This effect was more pronounced in female mice, which might indicate that hormonal changes that appear during their sexual cycle could influence the efficacy of some probiotics. Different mechanisms can explain this outcome-mainly, the ability of probiotics to compete with pathogens for adhesion sites, increase intestinal mucosal barrier activity, synthesize antimicrobial agents, and modulate the host's immune system [14-16].

The mechanism behind the immunomodulation exhibited by probiotics involves interactions between these microorganisms and the gut-associated lymphoid tissue (GALT), which is an important local immune compartment. Probiotics can modulate the activity of several cells that compose GALT, such as enterocytes, dendritic cells, and T-cells, therefore increasing the protection against intestinal infections [25-28]. Furthermore, evidence regarding the role of gastrointestinal bacteria on nematode infections can be found in the correlation between microbiota composition and parasite species infections [28].

The results of the current study showed only a moderate inhibition capacity of $L$. casei and L. paracasei on T. britovi larvae and a stronger one against adult parasites. Considering the lack of previous research on the effects of probiotics on T. britovi, the interpretation of the obtained results is somewhat difficult. Therefore, several studies conducted on T. spiralis will be further used for comparison.

In the current study, $10^{5} \mathrm{CFU} / \mathrm{mL} /$ animal in $100 \mu \mathrm{L}$ of Ringer's solution was administered to each mouse. In contrast, other studies used different doses. For example, in one study, $1.9 \times 10^{9} \mathrm{CFU} / \mathrm{mL}$ of viable L. casei was orally administered to mice seven days before $T$. spiralis infection. This latter dose induced a significantly protective response against trichinellosis [29].

The current experimental protocol used two strains of Lactobacillus (L. casei and L. paracasei) and tested the mice on days 9 and 32 p.i., whereas other similar studies included a higher number of Lactobacillus strains and tested the animals during other time frames. In the study by El Temsahy et al. [21], among L. plantarum, L. casei, and L. acidophilus, the most effective in reducing the number of T. spiralis larvae in male Swiss mice, on day 28 p.i., was L. plantarum (87\%), followed by L. casei (75\%), and finally L. acidophilus (61\%). Dvoroznáková et al. [22] found that on day 18 p.i., the number of T. spiralis larvae in BALB/c male mice was under 10/mouse, as assessed by artificial digestion, in the groups treated with L. fermentum, L. plantarum, E. faecium, and E. durans. Likewise, in another study, a significant decrease in the number of muscle larvae was detected on days 25 and 32 p.i. in the groups of BALB/c male mice that received L. fermentum AD1-CCM7420 and L. plantarum 17L/1 probiotic strain, and E. faecium AL41 and E. durans ED26E/7 bacteriocinproducing strains, respectively [23]. In the case of this latter study, the production of larvae was evaluated by the reproductive capacity index (RCI). The administration of E. faecium CCM8558, E. durans ED26E/7, L. fermentum CCM7421, and L. plantarum 17L/1 strains in male BALB/c mice resulted in a significant $T$. spiralis larval reduction, with a higher efficacy seen on day 25 p.i. $(13,220-23,250$ larvae/mice) [23].

The present study also suggests that the probiotics used might influence the local immune response of the host at the intestinal level, influencing the adults' reproductive capability. This theory is supported by other similar experimental protocols. Vargová et al. [9] showed that the administration of E. faecium EF55, E. faecium CCM7420, E. faecium CCM8558, E. durans ED26E/7, L. fermentum CCM7421, and L. plantarum 17L/1 influenced T. spiralis in male BALB/c mice during the intestinal and muscular phase of infection, while it may also influence the host's macrophagic activity. Both lactobacilli stimulated the metabolic activity of macrophages during the intestinal and early muscular phase of the infection (days 5 to 25 p.i). However, in the same study, enterococci increased the $\mathrm{O}_{2}$ - production in the intestinal phase (day 5 p.i.) and during the muscular phase (days 25 and 32 p.i.) of this parasitic infection. The detection of helper CD4, cytotoxic CD8 
T lymphocytes, and B lymphocytes in the small intestine of mice treated with probiotic strains and infected with T. spiralis was observed in a similar experiment [30]. Lactobacillus fermentum CCM7421 and L. plantarum 17L / 1 increased the numbers of helper CD4 T cells in the epithelium and cytotoxic CD8 T cells in the lamina propria on the 7th day of administration (before parasitic infection) [30]. Moreover, an $83.3 \%$ reduction in the burden of $T$. spiralis muscle larvae was observed on day 28 p.i. in female BALB/c mice which were immune-stimulated with NC8-pSIP409-pgsA-mIL-4 (IL-4 co-expressed with pgsA anchor system of Lactobacillus plantarum NC8 and delivered by live Lactobacillus plantarum NC8) [31].

Similar studies involving the use of probiotics have been conducted on other parasitic infections. A good example is an experimental study in mice (30 Swiss female mice) infected with Toxocara canis (100 eggs) and inoculated with Saccharomyces boulardii $\left(10^{7} \mathrm{CFU} / \mathrm{g}\right)$. The probiotic used promoted a reduction in the intensity of T. canis infection and modulated cytokine mRNA expression [32]. Another study investigated the effect of Bifidobacterium lactis subspecies animalis $\left(3.5 \times 10^{10} \mathrm{CFU}\right)$ on the immune and intestinal function of young pigs subsequently infected with Ascaris suum eggs (100/animal). The probiotic treatment significantly increased mRNA expression of genes associated with enhanced protection against parasitic infection, including IL-25, RETNLB, and SOCS3, and did not interfere with the normal expulsion of L4 from the jejunum [33].

\section{Materials and Methods}

\subsection{Animals}

Male $(n=40)$ and female $(n=40)$ white CD-1 mice, six to eight weeks old, weighing 20-30 g each, were used for the present study. The decision to add female mice to the experimental protocol was taken to observe if the hormonal changes that occur during their sexual cycle would influence the efficiency of the chosen probiotics. The mice were kept in the rodent facility of the University of Agricultural Sciences and Veterinary Medicine (UASVM) Cluj-Napoca (Romania) with the approval of the Ethics Committee of the same university, through permit number 265/12.07.2021. Mice were housed in clean polypropylene-covered cages, in a well-ventilated room $\left(24 \pm 2{ }^{\circ} \mathrm{C}\right)$ with relative humidity $(42 \pm 2 \%)$ and a 12:12 h light: dark cycle. The mice were fed with standard pellet food with free access to drinking water, under strict hygiene conditions. The bedding was changed weekly. Before the experiment, the mice were given five days to adapt to the laboratory environment.

\subsection{Probiotic Strains and Parasites}

Lactobacillus casei ATCC 393 strain was obtained from the Department of Food Science, UASVM Cluj-Napoca, while L. paracasei CNCM was purchased from a local pharmaceutical company (Sofar, Bucharest, Romania).

The T. britovi larvae that were used during the present experiment were previously isolated from a wolf (Canis lupus), with the species confirmed by molecular biology (Multiplex Polymerase Chain Reaction) at UASVM Cluj-Napoca and kept alive in the Parasitology Department, Faculty of Veterinary Medicine, UASVM Cluj-Napoca (Romania), until the experiment [34].

\subsection{Experimental Design}

The experimental design and protocol were approved by the Veterinary Sanitary and Food Safety Department in Cluj-Napoca, with the permit number 277, and by the Ethics Committee of the UASVM Cluj-Napoca (Romania) and respected the national legislation (Law 43/2014) and European legislation (EU Directive 63/2010), respectively.

Animals were randomly divided into four groups, each with two female and two male replicates at five mice/cage $(n=20)$ (Table 4). Probiotic strains were administered orally, in a daily dose of $10^{5} \mathrm{CFU} / \mathrm{mL} / \mathrm{animal}$, in $100 \mu \mathrm{L}$ of Ringer's solution. The mice were infected with 100 larvae/animal of $T$. britovi, on the $7^{\text {th }}$ day of treatment. On day 9 p.i., 10 
mice (5 females and 5 males) from each group were euthanized (cervical dislocation), then their intestinal walls and intestinal content were examined. On day 32 p.i., the remaining 10 mice (5 females and 5 males) from each group were euthanized (cervical dislocation), and muscle samples were evaluated by trichinoscopy and artificial digestion.

Table 4. The groups in the experimental protocol, the number of animals used, the doses of probiotics used, and the number of $T$. britovi larvae used for the experimental infection.

\begin{tabular}{|c|c|c|c|c|c|}
\hline Group & Abbreviation & No. of Females & No. of Males & Dose of Probiotics & Experimental Infection \\
\hline $\begin{array}{c}\text { Negative control } \\
\text { group }\end{array}$ & NC & 10 & 10 & - & - \\
\hline $\begin{array}{l}\text { Positive control } \\
\text { group }\end{array}$ & PC & 10 & 10 & - & $\begin{array}{c}100 \text { larvae of } \\
\text { T. britovi/animal }\end{array}$ \\
\hline $\begin{array}{l}\text { L. casei ATCC } 393 \\
\text { experimental } \\
\text { group }\end{array}$ & L. casei & 10 & 10 & $\begin{array}{c}10^{5} \mathrm{CFU} / \mathrm{mL} \text { in } \\
100 \mu \mathrm{L}\end{array}$ & $\begin{array}{l}100 \text { larvae of } \\
\text { T. britovi/animal }\end{array}$ \\
\hline $\begin{array}{l}\text { L. paracasei } \mathrm{CNCM} \\
\text { experimental } \\
\text { group }\end{array}$ & L. paracasei & 10 & 10 & $\begin{array}{c}10^{5} \mathrm{CFU} / \mathrm{mL} \text { in } \\
100 \mu \mathrm{L}\end{array}$ & $\begin{array}{l}100 \text { larvae of } \\
\text { T. britovi/animal }\end{array}$ \\
\hline
\end{tabular}

\subsection{Collection of Adult Parasites from the Intestinal Contents and Walls of Mice}

To obtain the intestinal content, 10 mice ( 5 females and 5 males) were euthanized from each of the 4 groups on day 9 p.i. Afterward, the intestines were collected and cut transversally in segments of 5-10 cm. Each obtained segment was then cut longitudinally to gain access to the content and placed in a sieve in a conical container with saline $(0.9 \% \mathrm{NaCl})$ solution. The samples were incubated at $37^{\circ} \mathrm{C}$ for $4-5 \mathrm{~h}$. Finally, the obtained sediment was examined with a $60 \times$ stereomicroscope (Olympus Bx61, Olympus Europe Holding, Hamburg, Germany) to count the adult parasites. The intestinal segments used in the previous step were collected and digested using the artificial digestion method as described in previously published articles and EU regulations [35], following the official protocol [34], to count the adults (females) in the intestinal mucosa.

\subsection{Trichinoscopy and Artificial Digestion}

The presence and distribution of Trichinella larvae in various muscle groups were determined through trichinoscopy. From each mouse, one compressor with 28 sections was examined as follows: masseter muscle -3 positions, diaphragm muscle -5 positions, forearm muscle -10 positions ( 5 left, 5 right), and hind leg muscles -10 positions (5 left, 5 right). The samples were examined at $4 \times$ magnification [3]. The mice carcasses (without fur, skin, and internal organs) used in the previous step were collected and digested individually with the artificial digestion method [35], following the official protocol [34], to count the larvae.

\subsection{Statistical Analysis}

Arithmetic mean and standard error of the mean were calculated for adults and larvae of T. britovi obtained after experimental infection in mice at 9 and 32 days p.i. by different techniques. These were computed by the gender of mice (females and males) and, in total, in the experimentally infected groups using MedCalc®Statistical Software version 20.014 [36]. Then, all data were analyzed by one-way ANOVA and Tukey-Kramer HSD test using online software. The level of significance was set at 0.05 [37]. 


\section{Conclusions}

The current experimental study in a murine model showed that L. casei ATCC 393 and L. paracasei $\mathrm{CNCM}$ are two probiotics that could potentially impact the development of the intestinal stage of T. britovi, although the exact mechanism behind this process needs further research. The results of the present study also indicated that L. casei ATCC 393 may be more efficient in reducing the number of $T$. britovi adults in female mice than $L$. paracasei $C N C M$.

Author Contributions: Conceptualization, Z.B., M.H.B., A.C.-P. and V.C.; methodology, Z.B., M.H.B., D.C.V. and C.M.G.; software, M.H.B. and A.G.; validation, C.M.G., S.-D.B., M.L. and V.C.; resources, D.C.V. and V.C.; writing - original draft preparation, Z.B. and M.H.B.; writing-review and editing, D.C.V., C.M.G., S.-D.B., A.C.-P., M.L., A.G. and V.C.; supervision, C.M.G. and V.C.; funding acquisition, D.C.V. and V.C. All authors have read and agreed to the published version of the manuscript.

Funding: The publication of this scientific article was supported by funds from the University of Agricultural Sciences and Veterinary Medicine of Cluj-Napoca, Romania (grant number 14 PFE).

Institutional Review Board Statement: The study was conducted in accordance with the Declaration of Helsinki and approved by the Ethics Committee of the University of Agricultural Sciences and Veterinary Medicine of Cluj-Napoca, Romania (Permit no. 265/12.07.2021)

Informed Consent Statement: Not applicable.

Data Availability Statement: Not applicable.

Conflicts of Interest: The authors declare no conflict of interest.

\section{References}

1. Pozio, E.; Hoberg, E.; La Rosa, G.; Zarlenga, D.S. Molecular taxonomy, phylogeny and biogeography of nematodes belonging to the Trichinella genus. Infect. Genet. Evol. 2009, 9, 606-616. [CrossRef] [PubMed]

2. Şuteu, I.; Cozma, V. Parazitologie Clinică Veterinară [Clinical Veterinary Parasitology]; Risoprint: Cluj-Napoca, Romania, 2012; Volume 2, p. 133.

3. Blaga, R.; Gherman, C.; Cozma, V.; Zocevic, A.; Pozio, E.; Boireau, P. Trichinella species circulating among wild and domestic animals in Romania. Vet. Parasitol. 2009, 159, 218-221. [CrossRef]

4. Cironeanu, I.; Ispas, A.T. Totul despre Trichineloză [All about Trichinellosis]; MAST Publishing House: Bucharest, Romania, 2002; pp. 9-15.

5. Pozio, E. Trichinella and trichinellosis in Europe. Vet. Glas. 2019, 73, 65-84. [CrossRef]

6. Neghina, R. Trichinellosis, a Romanian never-ending story. An overview of traditions, culinary customs, and public health conditions. Foodborne Pathog. Dis. 2010, 7, 999-1003. [CrossRef]

7. Rostami, A.; Gamble, H.R.; Dupouy-Camet, J.; Khazan, H.; Bruschi, F. Meat sources of infection for outbreaks of human trichinellosis. Food Microbiol. 2017, 64, 65-71. [CrossRef] [PubMed]

8. Gottstein, B.; Pozio, E.; Nöckler, K. Epidemiology, diagnosis, treatment, and control of trichinellosis. Clin. Microbiol. Rev. 2009, 22, 127-145. [CrossRef]

9. Vargová, M.; Hurníková, Z.; Revajová, V.; Lauková, A.; Dvorožňáková, E. Probiotic bacteria can modulate murine macrophage’s superoxide production in Trichinella spiralis infection. Helminthologia 2020, 57, 226. [CrossRef] [PubMed]

10. Saracino, M.P.; Vila, C.C.; Baldi, P.C.; Maglio, D.H.G. Searching for the one(s): Using probiotics as anthelmintic treatments. Front. Pharmacol. 2021, 12, 714198. [CrossRef]

11. Hill, C.; Guarner, F.; Reid, G.; Gibson, G.R.; Merenstein, D.J.; Pot, B.; Sanders, M.E. Expert consensus document: The International Scientific Association for Probiotics and Prebiotics consensus statement on the scope and appropriate use of the term probiotic. Nat. Rev. Gastroenterol. Hepatol. 2014, 11, 506-514. [CrossRef]

12. Mombelli, B.; Gismondo, M.R. The use of probiotics in medical practice. Int. J. Antimicrob. Agents 2000, 16, 531-536. [CrossRef]

13. Haakensen, M.; Dobson, C.M.; Hill, J.E.; Ziola, B. Reclassification of Pediococcus dextrinicus (Coster and White 1964) Back 1978 (Approved Lists 1980) as Lactobacillus dextrinicus comb. nov., and emended description of the genus Lactobacillus. Int. J. Syst. Evol. Microbiol. 2009, 59, 615-621. [CrossRef] [PubMed]

14. Berrili, F.; Di Cave, D.; Cavalero, S.; D'amelio, S. Interactions between parasites and microbial communities in the human gut. Front. Cell. Infect. Microbiol. 2012, 2, 141. [CrossRef] [PubMed]

15. Donelli, G.; Vuotto, C.; Mastromarino, P. Phenotyping and genotyping are both essential to identify and classify a probiotic microorganism. Microb. Ecol. Health Dis. 2013, 24, 20105. [CrossRef] [PubMed]

16. Butel, M.J. Probiotics, gut microbiota and health. Med. Mal. Infect. 2014, 44, 1-8. [CrossRef]

17. Humen, M.A.; De Antoni, G.L.; Benyacoub, J.; Costas, M.E.; Cardozo, M.I.; Kozubsky, L.; Pérez, P.F. Lactobacillus johnsonii La1 antagonizes Giardia intestinalis in vivo. Infect. Immun. 2005, 73, 1265-1269. [CrossRef] [PubMed] 
18. McClemens, J.; Kim, J.J.; Wang, H. Lactobacillus rhamnosus ingestion promotes innate host defense in an enteric parasitic infection. Clin. Vaccine. Immunol. 2013, 20, 818-826. [CrossRef]

19. Bautista-Garfias, C.R.; Ixta, O.; Orduña, M.; Martínez, F.; Aguilar, B.; Cortés, A. Enhancement of resistance in mice treated with Lactobacillus casei: Effect on Trichinella spiralis infection. Vet. Parasitol. 1999, 80, 251-260. [CrossRef]

20. Martínez-Gómez, F.; Santiago-Rosales, R.; Bautista-Garfias, C.R. Effect of Lactobacillus casei Shirota strain intraperitoneal administration in CD1 mice on the establishment of Trichinella spiralis adult worms and on IgA anti-T. spiralis production. Vet. Parasitol. 2009, 162, 171-175. [CrossRef]

21. El Temsahy, M.M.; Ibrahim, I.R.; Mossallam, S.F.; Mahrous, H.; Bary, A.A.; Salam, S.A.A. Evaluation of newly isolated probiotics in the protection against experimental intestinal trichinellosis. Vet. Parasitol. 2015, 214, 303-314. [CrossRef]

22. Dvorožňáková, E.; Bucková, B.; Hurníková, Z.; Revajová, V.; Lauková, A. Effect of probiotic bacteria on phagocytosis and respiratory burst activity of blood polymorphonuclear leukocytes (PMNL) in mice infected with Trichinella spiralis. Vet. Parasitol. 2016, 231, 69-76. [CrossRef]

23. Bucková, B.; Hurníková, Z.; Lauková, A.; Revajová, V.; Dvorožňáková, E. The anti-parasitic effect of probiotic bacteria via limiting the fecundity of Trichinella spiralis female adults. Helminthologia 2018, 55, 102-111. [CrossRef] [PubMed]

24. Reynolds, L.A.; Finlay, B.B.; Maizels, R.M. Cohabitation in the intestine: Interactions among helminth parasites, bacterial microbiota, and host immunity. J. Immunol. 2015, 195, 4059-4066. [CrossRef] [PubMed]

25. Sánchez, B.; Delgado, S.; Blanco-Míguez, A.; Lourenço, A.; Gueimonde, M.; Margolles, A. Probiotics, gut microbiota, and their influence on host health and disease. Mol. Nutr. Food Res. 2017, 61, 1600240. [CrossRef]

26. De Le Blanc, A.M.; Matar, C.; Perdigón, G. The application of probiotics in cancer. Br. J. Nutr. 2007, 98, S105-S110. [CrossRef] [PubMed]

27. Friedrich, A.D.; Paz, M.L.; Leoni, J.; González Maglio, D.H. Message in a bottle: Dialog between intestine and skin modulated by probiotics. Int. J. Mol. Sci. 2017, 18, 1067. [CrossRef] [PubMed]

28. Randazzo, V.; Costamagna, S.R. Effect of oral administration of probiotic agents on Trichinella spiralis-infected mice. Rev. De Patol. Trop./J. Trop. Pathol. 2005, 34, 129-135. [CrossRef]

29. Dvoroznakova, E.; Vargova, M.; Laukova, A.; Revajova, V. Modulatory effect of probiotic therapy on intestinal lymphocytes in mice infected with Trichinella spiralis. Theory Pract. Combat. Parasit. Dis. 2019, 20, 741-745. [CrossRef]

30. Wang, D.; Gong, Q.L.; Huang, H.B.; Yang, W.T.; Shi, C.W.; Jiang, Y.L.; Wang, J.Z.; Kang, Y.H.; Zhao, Q.; Yang, G.L.; et al. Protection against Trichinella spiralis in BALB/c mice via oral administration of recombinant Lactobacillus plantarum expressing murine interleukin-4. Vet. Parasitol. 2020, 280, 109068. [CrossRef] [PubMed]

31. Wassom, D.L.; Dougherky, D.A.; Dick, T.A. Trichinella spiralis infection of inbred mice: Immunological specific responses induced by different Trichinella isolates. J. Parasitol. 1988, 42, 283-287. [CrossRef]

32. de Avila, L.D.C.; De Leon, P.M.M.; De Moura, M.Q.; Berne, M.E.A.; Scaini, C.J.; Leivas Leite, F.P. Modulation of IL-12 and IFN $\gamma$ by probiotic supplementation promotes protection against Toxocara canis infection in mice. Parasite Immunol. 2016, 38, 326-330. [CrossRef] [PubMed]

33. Solano-Aguilar, G.; Shea-Donohue, T.; Madden, K.; Dawson, H.; Beshah, E.; Jones, Y.; Urban, J. Feeding probiotic bacteria to swine enhances immunity to Ascaris suum. Vet. Immunol. Immunopath. 2009, 128, 293-294. [CrossRef]

34. Gamble, H.R.; Bessonov, A.S.; Cuperlovic, K.; Gajadhar, A.A.; Van Knapen, F.; Noeckler, K.; Schenone, H.; Zhu, X. International Commission on Trichinellosis: Recommendations on methods for the control of Trichinella in domestic and wild animals intended for human consumption. Vet. Parasitol. 2000, 93, 393-408. [CrossRef]

35. European Commission. Commission Implementing Regulation (EU) 2015/1375 of 10 August 2015 Laying down Specific Rules on Official Controls for Trichinella in Meat (Codification). Off. J. Eur. Union 2015, 212, 7-34. Available online: https: / / eur-lex.europa.eu/legal-content/EN/TXT/PDF/?uri=CELEX:32015R1375\&from=HR (accessed on 16 December 2021).

36. MedCalc Software Ltd. Ostend, Belgium. 2012. Available online: https:/ / www.medcalc.org (accessed on 15 December 2021).

37. Assaad, H.I.; Hou, Y.; Zhou, L.; Carroll, R.J.; Wu, G. Rapid publication-ready MS-Word tables for two-way ANOVA. Springerplus 2015, 4, 33. [CrossRef] [PubMed] 